Barnett R. Rubin

\title{
BEYOND STALEMATE IN AFGHANISTAN
}

DOI: 10.20542/2307-1494-2017-1-244-250

Keywords: Afghanistan, United States, Pakistan, Iran, China, India, Russia, Central Asia, "The Belt and Road Initiative", regional cooperation, Afghan peace process, Taliban, Islamic State

Abstract: For the first time since 2001, Afghanistan and all regional powers agree in principle to include the Taliban in a peace process. That remains U.S. policy as well, though the Trump administration is yet to review or reaffirm it. The U.S. could decide that stability or peace in Afghanistan are unattainable, and that the best option would be to maintain a platform in Afghanistan to fight terrorism. The regional economic transformations, however, raise the cost of that stalemate to Afghanistan's neighbors who might welcome U.S. participation with them in a stabilization or peace process, as long as it leads to the eventual departure of U.S. troops rather than their entrenchment in the region. If success in Afghanistan means stabilization, the way to achieve it would be a diplomatic strategy to transition from a U.S. military presence in Afghanistan to a regionally supported political settlement that eliminates the need for that presence.

Ключевые Афрганистан, США, Пакистан, Иран, Китай, Индия, Россия, Центральная Азия, слова: инициатива «Один пояс, один путь», региональное сотрудничество, афганский мирный процесс, Талибан, «Исламское государство»

Аннотация: Впервые с 2001 г. Афрганистан и все региональные державы в принципе согласны с тем, что движение Талибан должно стать участником мирного процесса. Эта позиция пока остается и официальным курсом США, хотя администрации Трампа еще предстоит пересмотреть или подтвердить ее. США могут решить, что стабильность и мир в Афрганистане недостижимы и что лучший выбор в таких условиях - сохранить военный плацдарм в этой стране для борьбы с терроризмом. Однако сдвиги в региональной экономике повышают издержки такого тупикового варианта для соседей Афрганистана, которые могут позитивно воспринять совместное с ними участие США в процессе мирного урегулирования и стабилизации, но лишь если оно, в конечном счете, приведет к выводу американских сил, а не к их сохранению в регионе на неопределенный срок. Если для США «успех» в Афрганистане означает стабилизацию, то путем к ней может быть дипломатическая стратегия по переходу от военного присутствия к политическому урегулированию при поддержке стран региона, которое сделает такое присутствие ненужным. 


\section{Introduction}

To understand why the United States is stalemated in Afghanistan, one needs only read the testimony of General John W. Nicholson, Commander, U.S. ForcesAfghanistan, before the Senate Armed Services Committee on February 9, 2017. General Nicholson discussed the number and disposition of troops that might improve the terms of the current stalemate. This is the one factor General Nicholson can affect. Despite the tremendous sacrifices it will entail from the Afghan forces, it has little bearing on the war's outcome.

The continuation for nearly forty years of a war that has passed seamlessly through stages as a Cold War proxy conflict, a regionally fuelled ethno-factional war, and a global struggle against extremism and terrorism shows that the source of violent conflict and instability in Afghanistan is not communism, ethnic antagonism, Islamic extremism, malign neighbors like the USSR, Pakistan, Iran, or Russia, American imperialism, or a war on Islam by Crusaders and Zionists. Afghanistan's core problem is that it is a landlocked state whose economy, ranked 172 out of 184 countries in GDP per capita by the International Monetary Fund (IMF), cannot pay the cost of governing or defending a population scattered in enclaves separated by arid, mountainous territory. Ever since its demarcation in its current borders by the British and Russian empires at the end of the nineteenth century, the Afghan state has needed foreign subsidies to survive. Its stability depends on an international consensus to support those subsidies.

\section{Current regional and international set-up on Afghanistan}

The current state is sustained by about USD 13 billion a year from the United States alone. Funding the security forces to preserve the current stalemate requires at least USD 4 billion per year. Access to Afghanistan by an offshore power like the United States requires the cooperation of Pakistan, Iran, or Russia. As long as Washington enforces sanctions against both Iran and Russia, its access to Afghanistan depends on Pakistan, which provides a safe haven to the Taliban to pressure the U.S. and the Afghan government over the Indian presence there and Afghanistan's territorial claims against Pakistan. Measures that some have proposed to pressure Pakistan to close the safe haven for the Taliban - sanctions, designation as a state sponsor of terror, crossborder attacks, or cancellation of bilateral assistance - could lead Islamabad to cut those supply lines. When it did so after a series of security incidents in 2011, the United States had and used a choice of supplying its forces in Afghanistan through Russia and Central Asia. The U.S. cannot do so in the current state of the U.S.-Russia relations, and transit through Iran remains impossible.

Afghanistan needs years more of substantial aid from the United States and its partners, as they have pledged at NATO and donor conferences, but it also needs cooperative relations with its neighbors. Growth of a landlocked economy requires cooperation with neighbors for access to markets. Reliable cooperation will come only 
through a political settlement that addresses the concerns of regional states, as well as the Taliban, whom some of these states use to pressure the U.S. to withdraw its troops.

After 9/11 the United States, alongside Russia and Iran, supported the Northern Alliance against al Qaeda and the Taliban. As the Taliban insurgency supported by Pakistan spread and success eluded the U.S., its presence started to look permanent. Neighbors began to regard U.S. bases in the region as a threat. As early as July 2005, at a summit meeting of the Shanghai Cooperation Organization in Astana, Kazakhstan, the heads of state expressed the wish that, "members of the antiterrorist coalition set a final timeline for their temporary use of [basing facilities] and stay of their military contingents on the territories of the SCO member states".

At a gathering in Dubai in December 2010, Russian Presidential Special Envoy on Afghanistan Zamir Kabulov claimed, as he did again when the author met him in Moscow in December 2016, that the military infrastructure built by the United States would enable it to surge 100000 troops into Afghanistan to intervene throughout the region. He has publicly stated that this is as unacceptable to Moscow as Russian bases in Cuba would be to Washington. Iranian officials evoke a similar scenario, arguing both that the U.S. presence destabilizes Afghanistan and that U.S. bases in Afghanistan constitute a threat to Iran.

The Pakistani military sees that the U.S. and Indian national interests are increasingly aligned. As one official told U.S. diplomats in June 2011, a month after the raid that killed Osama Bin Laden, Pakistan did not want the U.S. to be able to carry out "drive-by interventions" in Pakistan. These interventions could target Pakistan's nuclear weapons, which some in the security establishment believe to be the ultimate target of U.S. forces in Afghanistan.

\section{China and India: economics and beyond}

For many years, China echoed the Russian and Iranian position. By 2012, however, China concluded that the stability of Afghanistan was a vital national interest, both because of the threat of terrorism and separatism in Xinjiang and also security required for Beijing's regional investment plans. While China still opposes "permanent" U.S. bases in Afghanistan in principle, it has become more common for the Chinese to express concern about a premature troop withdrawal.

The immense changes in the region set off by the growth of the Chinese and Indian economies mean that Afghanistan's neighbors now have more to lose from insecurity in Afghanistan. China has staked its economic future on connecting its western region to global markets through "The Belt and Road Initiative" (BRI) - a revised name employed since 2016 for the 2013 "One Belt, One Road" (OBOR) initiative. China has announced initial plans to invest USD 160 billion in the first stage, including USD 46 billion for the China-Pakistan Economic Corridor (CPEC). BRI has become the signature project of President Xi Jinping's ten-year term. His legacy depends on it. 
The Silk Road Economic Belt is planned as a network of roads, railroads, and pipelines connecting China to Central Asia, the Middle East and Europe. The Maritime Silk Road would consist of a string of ports around the Indian Ocean. The ChinaPakistan Economic Corridor (CPEC), which connects Xinjiang to the port of Gwadar in Balochistan, links the two parts of this grand design. In a December conversation with the author in Moscow, Ramzan Daurov, head of the Afghanistan Department, Institute of Oriental Studies of the Russian Academy of Sciences, called BRI "the biggest project in the history of mankind".

Chinese officials have been encouraging India's participation in this scheme. At the February 22, 2017 China-India Strategic Dialogue in Beijing, China urged India to send a high-level representative to the BRI summit planned for the summer of 2017 and discussed possible cooperation in Afghanistan. Connecting with CPEC and BRI would provide New Delhi with the overland link to Kabul and Central Asia that it lost in 1947. India's principal objection is that CPEC crosses territory that India claims as a part of the state of Jammu and Kashmir. Indian Foreign Secretary Jaishankar told his Chinese counterpart that CPEC "violates Indian sovereignty", but he noted that India supports connectivity and "would like to see what proposals anybody has in that regard".

India has started its own connectivity project in partnership with Iran. The two countries have developed the Iranian port of Chabahar on the Arabian Sea. From there Iran has built both a rail line and a road to the Afghan border. India has built a highway linking the Iranian road to Afghanistan's ring road. A tripartite transit agreement among India, Iran, and Afghanistan enables Afghanistan and India to circumvent Pakistan's closed border by trading through Chabahar. In January 2017, Japan joined the consortium out of concern over Chinese naval expansion in the Indian Ocean. This partnership could give Afghanistan an alternative to logistical and economic dependence on Pakistan.

$\mathrm{BRI}$ and Chabahar may be linked into a single network. During a visit to Pakistan in March 2016, Iranian President Hassan Rouhani proposed linking CPEC to Chabahar and proceeding with the long-planned Iran-Pakistan-India gas pipeline. A few months ago Iranian senior officials addressing a high-level Chinese think-tank and diplomatic delegation urged China to link BRI with Chabahar.

In addition to the tripartite transit agreement on Chabahar Afghanistan has also signed a memorandum of understanding with Beijing over participation in BRI. A new railroad line is carrying consumer goods from China's Jiangsu Province to the Afghan port of Hairatan on the Uzbekistan border. Iranian trains have started carrying goods up to the Afghan border.

This context provides opportunities for diplomacy in forms other than bilateral engagement or pressure focused on counterterrorism. Chinese officials say that they consider the stability of Afghanistan vital to BRI, which means that Afghanistan's stability is a personal concern of President Xi Jinping. The head of a Chinese think tank told the author in December 2016 that "China has different national interests than Pakistan in Afghanistan". For several years, whenever Islamabad has approached Beijing to relieve 
pressure it was feeling from the United States, China has counseled Islamabad to mend relations with Washington. It has tried to persuade Pakistan to take stronger measures to bring the Taliban into a peace process.

China's foreign policy elite has varied views on how to deal with Pakistan: an influential minority wants to use China's leverage to press Pakistan more firmly to stop destabilizing Afghanistan and favors some cooperation with India. At a meeting in Bishkek, Kyrgyzstan in June 2016, the Chinese delegation from several think tanks was divided as to how China would respond to a proposal in the UN Security Council to impose sanctions on individuals in Pakistan supporting the Taliban. Most strongly opposed such a measure, but one senior scholar suggested that China might abstain rather than veto such a resolution. Recently a group in the People's Liberation Army has advocated sending Chinese troops to Afghanistan. China has reportedly deployed counterterrorist units of the Ministry of the Interior for joint operations with the Afghan government against members of the East Turkistan Islamic Movement in northeast Afghanistan. U.S. cooperation with China is more likely to be effective in changing the Pakistan-Taliban relationship than a confrontation that will push China and Pakistan closer together.

\section{New diplomatic activity on the Afghan peace process: Russia and others}

Since the Taliban surged into Kandahar from Balochistan in 1994, Russia and Iran had not only opposed them, but had also tried to block attempts to include them in a political settlement. Both originally saw the Taliban as a Saudi-Pakistani-U.S. creation aiming to encircle Iran and secure southward pipeline and trade routes to loosen Central Asia's ties to Russia. Since 2008, however, the Taliban have mounted a diplomatic campaign to persuade the United States and Afghanistan's neighbors that, despite their evident dependence on Pakistan, they remain an autonomous actor that had nothing to do with 9/11 and have no hostile intent toward any country. Kabulov told a Turkish interviewer in December 2016 that "The bulk [of Taliban], main leadership, current leadership, and the majority of Taliban now - . . gave up the global jihadism idea. They are upset and regret that they followed Osama bin Laden". 1

Since the mid-2010s, the Taliban have also denounced the Islamic State, whose claim to extend the authority of its emirate to Afghanistan constitutes a direct challenge to their legitimacy. Kabulov has confirmed that, as a result, Russia has opened a channel of communication with the Taliban. The Taliban have also persuaded Iran that their common opposition to IS and the U.S. military presence outweighs past political and sectarian conflicts. This was reportedly the subject of discussion with Taliban leader Mullah Akhtar Muhammad Mansur during the trip to Iran - just before he was assassinated by a U.S. drone in Pakistan on May 25, 2016.

Russia has convened three regional meetings on Afghanistan. On December 26, 2016, Russia conducted talks with Pakistan and China, leading to protests from Afghan President Ashraf Ghani about excluding Afghanistan from discussions of its own fate. 
Russia regards the Ghani government, which signed the U.S.-Afghanistan bilateral security agreement providing for a U.S. military presence in Afghanistan, as excessively pro-American. The meeting's participants, who largely focused on the IS threat in the region, issued a statement calling for some members of the Taliban to be removed from sanctions lists to facilitate peace talks.

Along with Iran and India, Afghanistan attended the follow-up meeting in Moscow on February 15, 2017. Russian officials said they intended to invite the U.S. representative(s) when the Trump administration's team is in place. Russia did invite the United States to an expanded meeting including the Central Asian states as well on April 14, 2017, but the U.S. declined to attend.

Reversing its longstanding position, Russia has floated the idea of including the Taliban in the regional framework. In parallel, on March 8, 2017, China hosted a delegation of Taliban negotiators from their Qatar office. The Chinese Special Envoy on Afghanistan, Deng Lijun, stated that China told the Taliban that negotiations were their only path and urged them to meet the Afghan government. These meetings could be the prelude to the five powers and the U.S. reaching a greater degree of consensus with the Afghan government and the Taliban on the form a peace process would take.

\section{Implications for the United States}

For the first time since 2001, Afghanistan and all regional powers agree in principle to include the Taliban in a peace process. That remains U.S. policy as well, although the Trump administration is yet to review or reaffirm it. Negotiating with the Taliban conflicts with the view of political Islam promoted by presidential advisor Stephen Bannon, though it could be consistent with the views of National Security Advisor Lt.-General Herbert Raymond McMaster.

The U.S. could decide that stability and peace in Afghanistan are unattainable, and that the best option would be to maintain a platform in Afghanistan to fight terrorism and pressure "malign actors". This is what twenty former senior military commanders and diplomats recommended in a joint letter released by the Brookings Institution in October $2016 .^{2}$ The cost of doing so is indefinite continuation of the war and stalemate.

The regional economic transformations, however, raise the cost of that stalemate to Afghanistan's neighbors, a potential asset that the U.S. policy has ignored. The neighbors might welcome U.S. participation with them in a stabilization or peace process, as long as it leads to the eventual departure of U.S. troops rather than their entrenchment in the region. Whether to deny safe haven to terrorists, facilitate regionwide investment and connectivity, or enable Afghans to "die in their beds" as one defined their national aspiration, there is only one path: pursuit of a political settlement supported by all major powers in the neighborhood, leading to a negotiated, gradual end to the U.S. military presence. 
If success in Afghanistan means stabilization, the way to achieve it would be a diplomatic strategy to transition from a U.S. military presence in Afghanistan to a regionally supported political settlement that eliminates the need for that presence.

Positive engagement with, and support for, the regional connectivity efforts now underway - something for which U.S. Secretary of State Rex Tillerson's experience as CEO of "Exxon" should prepare him well - could serve as effective confidence building measures. It would show that the U.S. presence in the region can support the region's economic plans, rather than stage hostile interventions. It remains to be seen whether a U.S. President who says: "Islam hates us", views negotiations as zero-sum propositions, displays hostility toward Muslims around the world, opposes cooperation with Iran, and regards Islamism and Islamist politics as terrorism will be able to formulate a strategy consistent with political realities.

\section{ENDNOTES}

1 Exclusive interview with Russian diplomat Zamir Kabulov // Anadolu Agency. 31.12.2016. URL: $<$ http://aa.com.tr/en/asia-pacific/exclusive-interview-with-russian-diplomat-zamir-kabulov/717573>.

${ }^{2}$ Forging an Enduring Partnership with Afghanistan. The Brookings Institution Report. Washington D.C.: The Brookings Institution, 6 October 2016.

URL: <https://www.brookings.edu/research/forging-an-enduring-partnership-with-afghanistan/>. 